\title{
Governance Development Based On Village Fund Year 2016 In Bandung Regency Portrait of Unconstrained Village in the Establishment of Development Priorities (Study In Ciburial Village Cimenyan District Bandung Regency)
}

\author{
Rudiana \\ Department of Government Science Padjadjaran University, \\ Bandung Indonesia \\ Iyep Saefulrahman \\ Department of Government Science Padjadjaran University, \\ Bandung Indonesia
}

\begin{abstract}
Rural development is an integral part of village governance as a whole. Its success will have a significant impact on the progress and independence of the village and the welfare of its people. For this reason, the Government then disseminates the village fund policy. But in practice, the existence of these village funds makes the village only as the implementer of state policy and local government. This is because in village development governance, the power to prioritize development is not owned by the village but by the Regional Government. This problem is experienced by Ciburial Village located in Bandung Regency. With such problems, qualitative research becomes the right choice because it gives the discretion to express the meaning behind the apparent facts, analyzing the root of the problem and the consequences of the conditions that have occurred. The results of the study showed that as a legal community union which has the authority to manage and manage its own interests, Ciburial Village can not do much in managing the development in its territory. The presence of the state, through the Bandung Regency Government, remains dominant in determining the direction of village policy, so that the rural development base is not the need of the village and its people but the will of the regional government among which is set forth in the list of local government work plans. This condition indirectly indicates that in Ciburial Village, power as a unit of law society (autonomy) is merely a recognition has not become a force for sustainable progress and independence of the village.
\end{abstract}

Keywords: governance, village development, village funds

\section{INTRODUCTION}

Changes in the views and attitudes of the state towards the village through a package of policies governing the village, especially on village funds, deserve to be appreciated. Through a package of policies initiated by the issuance of Law No. 6 of 2014 on Villages which, among others, mandate the source of village revenues from the allocation of the State Budget (Article 72 letter b), the passion of village development is so strong and the enthusiasm of the community increases past times.

The package of policy was welcomed by the village as it would provide a great opportunity for the realization of the development objectives as well as the Medium Term Development Plan (RPJM) and the Long Term Development Plan (RPJP). The existence of village funds in the short term can be utilized to finance the implementation of annual work programs as outlined in the 
Rudiana., \& Saefulrahman, I. (2018). Governance Development Based On Village Fund Year 2016 In Bandung Regency Portrait of Unconstrained Village in the Establishment of Development Priorities (Study In Ciburial Village Cimenyan District Bandung Regency). Advances in Social Sciences Research Journal, 5(3) 333-341.

Government Work Plan (RKP). This is also in line with the objectives of the government when issuing a village fund policy that is for the village to finance the implementation of government, implementation of development, community development, and community empowerment.

Behind the positive objectives, there is a fact that is generally difficult to ignore that is related to the quality of human resources. As we know in the empirical level there are still many villages that lack support in terms of the ability of the village device. This is due to the lack of formal education of village apparatus to understand complex village financial management mechanisms. In addition to the skills aspect, lack of technology, especially in operating computer equipment, but to be able to manage the village financial system now the skill becomes an urgent need.

Based on the above description, it is natural that there is confusion in the village administration. This condition is further strengthened by various policies issued by the government. According to the prevailing provisions, this village fund involves not only one government namely the Central Government, but also the Regency / City Local Government. In addition, the involvement of 3 (three) ministries also increased the confusion of village government in understanding the provisions in the village fund governance because each ministry issued a provision that sometimes in its implementation is not synchronized or out of sync.

State aid (such as village funds), should be admittedly desperately needed, especially with the current village conditions. However, financing assistance is not a guarantee that the village will become sustainably sustainable, when the village has no control over itself, including to establish development priorities in the village. Based on empirical and historical facts such treatment of the country is the cause of the village is in the condition as now, not have the independence. State hegemony in the village in the past caused the village to be in a condition that lacked the ability to escape the problems that it faced, including from the poverty trap and the dependence on state aid.

As other villages that are part of NKRI, Ciburial Village located in Cimenyan District, West Bandung Regency can not avoid its obligation to implement village fund policy. Referring to the laws, government regulations and regulations of the three ministers, Ciburial started the village development financed by village funds in 2015. While for 2016, the legal basis is supplemented by Regent's Regulation No. 21 Year 2016 About the Village Fund Management Guidelines in Bandung Regency. Based on all these policies, the determination of development priorities in Ciburial Village becomes the authority of the state, in this case the Ministry of Village, Development of Disadvantaged Regions, and Transmigration. Through this policy the state takes over some of the village's power. This means that Ciburial Village has no power over the determination of development priorities, and only acts to implement the provisions set by the state. The state does not as a whole take the power of the village in development, because in determining its activities remain a village authority. However, the determination of development priorities is a very strategic policy for the village as it becomes the basis for the later development activities. Herein lies the problem because the development priorities set by the government (state) are often incompatible with the needs of the village and its people. Ultimately, village development results can not be enjoyed and utilized by the villagers and their citizens because they do not fit with what they need.

In the context of autonomy, good governance and reform as the ideals that the government wants to realize, including at the village level, the conditions experienced by Ciburial Village 
become an ironic matter. This is because the context implies the will to apply the principles of democracy and decentralization, the diversity based on locality, giving the widest access to public participation in government and development (bottom up), independence and empowerment of the village and its people. However, if faced with government policies related to village funds, the hope is difficult to be realized, especially at the village level which has many limitations when it comes to dealing with the state.

This paper, which is part of the Study on "Central, Regional, and Village Finance Relations", attempts to assess the empirical experience of village development management in Ciburial Village Cimenyan District Bandung Regency of West Java Province. The focus of the paper is directed to the analytical description of village imbalance in governance and development as a result of government policy related to the determination of development priorities based on village funds.

\section{LIBRARY REVIEW}

The village is a legal community unit that is authorized to organize and manage its own interests. With the existence of such authority, the village according to Nurcholis (2011) has a political, economic, judicial, socio-cultural, and self-developed defense and security institutions to meet their living needs. In the political-government context, all these powers are known as autonomy. On that basis, the village was essentially autonomous. But of course, the autonomy of the village is different from the regional autonomy and one of them according to Ndraha (1991) can be seen from the source, the autonomy of the village comes from local traditions and customs, while the regional autonomy from the central government granted through the law. To be able to exercise its authority, the village is also endowed with its own resources, self-managed and used to finance the interests of the village and its own community. One of the village's interests is in building the village.

In general, development is understood as an effort to make changes for the welfare of society can be achieved and continue to increase. This effort has an important position because it can bring progress and independence towards village and community. In this case development has a positive meaning as described by Kartasasmita (1996) that is as a process of change to a better direction through a planned effort done.

The above explanation shows that as a planned change effort, development can not be established and carried out just as it is. It takes an activity that can make development more meaningful. These activities are known by management. Etymologically management comes from the word "manus" (hand) and "agree" (do), which after having merged into "manaje" (take care). There is an expert view of the definition of management, one of which is George Terry who says that: "Management is the distinct process of consisting of planning, organizing, actuating, and controlling the performing to determine and accomplish stated objectives by the use of human being and other resources" in Kencana, 2011: 2).

The meaning of management is a process consisting of planning, organizing, implementation and supervision to achieve the objectives that have been determined with resources owned. In parallel in that regard, management can be done in almost all areas, including village finances. To examine the management of the Village Fund, the researcher uses the financial management theory proposed by Brian Binder, where the main elements of financial management can be classified into two groups: (1) periodic elements and legal elements, and (2) external and internal elements. Periodic Elements and Legal Elements: The periodic elements include elements that are part of the regular activities of the year, namely: developing programs and budgets; budget expenditure and revenues; money out and money coming in; record and 
report financial transactions. Legal elements include the elements of regulation and monitoring of regular activities, namely: financial laws and regulations; transactions and financial checks from within. External and Internal Elements: External elements include supervision imposed on village government by higher supervisory officers (central government, local government and sub-district), based on laws, regulations and guidelines; ratification of budgets and financial regulations, reports of external financial needs and audits. The element in is the element of monitoring and reporting conducted and conducted by the village government for the guidelines of village government finance officials. In simplicity the elements of the financial system of the government above are summarized in a picture below:

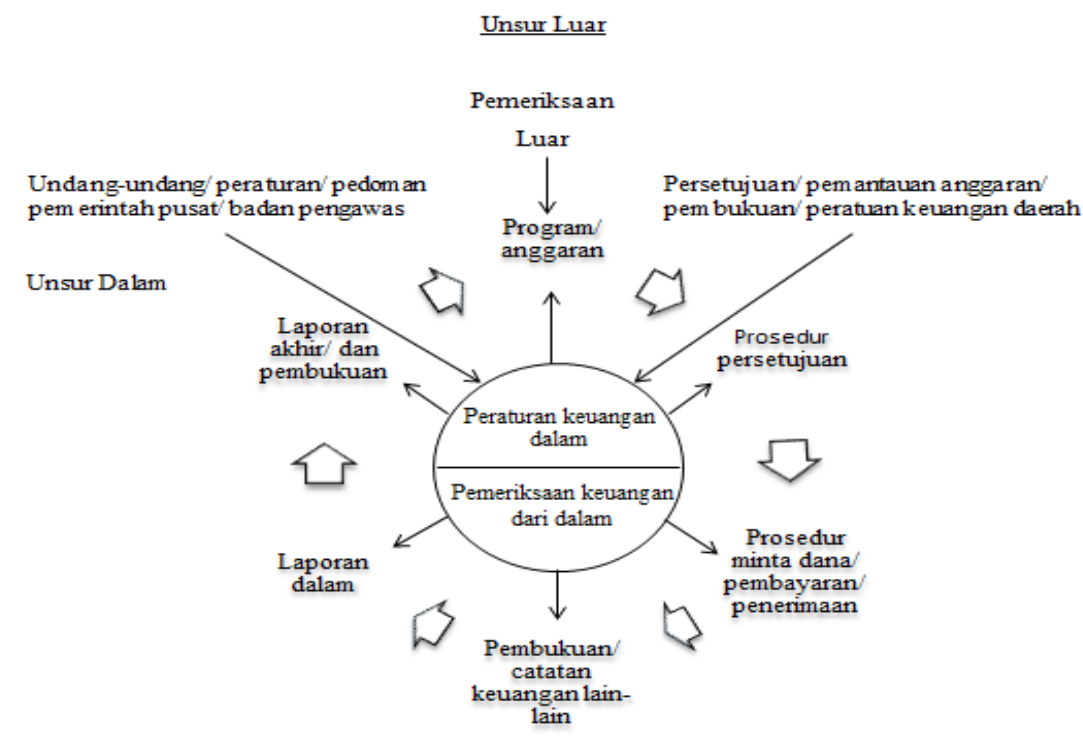

Figure 2.4 Key Elements of Financial Management System Source: (in Nick Devas, et al., 1989)

RESEARCH METHODS

The research method used is qualitative method. Qualitative research method is a method used to examine a condition that is natural or what it is (Sugiono, 2007). In addition, this qualitative method is used because some of the considerations are more easily adjusted when faced with a double reality, presenting directly the nature of the relationship between the researcher and the respondent and more sensitive and more adaptable to the many sharpening of mutual influence and the value patterns encountered (Moleong, 1996). This research departs from social problems, problems that exist in society and develops every time. With qualitative method, this research will be flexible or can adapt to the changes that exist.

An important thing in the writing of scientific papers research results are data and information of all objects that will be examined so that the writing becomes objective, rational, and factual. In connection with that Moleong (2008) mentioned the main data source in qualitative research is the words and the rest of the action is additional data such as documents, etc. Arikunto (2006) also argues that the intended source of data is the subject from which data is obtained. Furthermore, to make it easier to identify the data source, Arikunto identifies into three parts of the person, related to the data in the form of oral answers through interviews or written answers through questionnaire, place, a data source that provides a stationary and moving view and paper, as a data source that presents signs of letters, numbers, images or other symbols. 
To obtain information and facts as complete as possible from the empirical situation in this study, the authors use some data collection techniques. For the primary data used observation by doing a direct observation on the Governance of Development funded by village funds in Ciburial Village Cimenyan District Bandung Regency Year 2015-2016. Then interviews are not structured against informants or resource persons who have been set in accordance with the purpose of this study through purposive techniques namely Village Head; Village Secretary; Village Treasurer; Local Village Assistant; Chairman of BPD; Districts; Dinas PMD; Society. Furthermore, library research is needed to complement the primary data, obtained through literary research methods (liberary research). Secondary data collection is done by studying theoretical books, journals, scientific papers, documents, and reports, including various rules relating to research variables.

\section{RESULTS AND DISCUSSION}

In the implementation of village development in Ciburial, the funding has been sourced from the community. However, it does not mean that Ciburial Village did not get any help from the government because prior to the issuance of the village fund policy, the assistance for village development was obtained from the Bandung District Government's APBD through the Village Fund Allocation (ADD) and Provincial Assistance (Banprop) of West Java. The policies of the use of ADD and Banprop West Java are not all set by the aid providers. In general assistance, the village remains in charge of managing and utilizing it, whose determination is made through village deliberations. While the special aid designated and managed by the local government of aid providers. The special assistance is intended to finance the acceleration of village development, and community empowerment. Therefore, the village still has the power to set priorities for development in the village.

Different policies were taken by the government on the use of village funds because the government through the Ministry of Village, Disadvantaged Areas Development, and Transmigration (Kemendes PDTT), had first established the mechanism for managing and stipulating the priority of village development funded by the village fund program. It can be traced from the policy issued by Kemendes PDTT that is Permendes No. 21 of 2015 on the Establishment of Priority of Village Fund Usage Year 2016. Other policies that are also a reference in the management of village funds is the Regent Regulation No. 21 Year 2016 About the Village Fund Management Guidelines in Bandung Regency.

As stipulated in the other policy of Permendagri No. 114 of 2015 on Guidelines for Village Development, in principle, development in Ciburial Village is based on the needs of the community which is determined through the village development planning (musrenbang). The results are set forth in the RPJMDes which includes the proram of government and development during the elected term of the village head (6 years). It is further translated into annual action plans (RKPDes) prepared by the village head with the Village Consultative Board (Bamusdes). After the establishment of RKPDes, the Village Government of Cibuial subsequently compiled the Village Revenue and Expenditure Budget (APBDes).

In fact, in addition to the needs of the villagers, which should not conflict with the interests of the government, provincial governments, and district / city governments, the RPJMDes determination must also take into account "top-level needs (instructional areas / centers)". This is related to the implementation of programs whose sources of funding and use have been directed by the regions / centers.

The form of "instruction" is contained in the List of Regional Action Plans (DRKD) established by the Department of Village Community Empowerment (DPMD) Bandung Regency. In this 
Rudiana., \& Saefulrahman, I. (2018). Governance Development Based On Village Fund Year 2016 In Bandung Regency Portrait of Unconstrained Village in the Establishment of Development Priorities (Study In Ciburial Village Cimenyan District Bandung Regency). Advances in Social Sciences Research Journal, 5(3) 333-341.

case the DRKD acts as an instrument of government control of the regency in village development in Ciburial. Concrete form of the control of the Government of Bandung Regency is done with the participation of DPMD in establishing programs that can be implemented or realized by the Government of Ciburial Village. This is apparently related to the regional interest in the use of village finances sourced from the Village Fund does not conflict with or overlap with other sources (Allocation of Village Funds, Provincial Assistance, PADes).

With the control of the DPMD, the priority of the use of the Village Fund as set out in Permendes PDTT No. 21 of 2015 on the Establishment of the Priority of Village Fund Usage Year 2016 and the Regent Regulation No. 21 Year 2016 About the Village Fund Management Guidance in Bandung Regency can not be used as a guideline for planning the use of the Village Fund because in fact, the priority of planning the use of the Village Fund as set forth in these regulations can not be fully implemented by the village government. In the end, the Ciburial Village Government awaits the determination of priorities and directives issued by the Government of Badung Regency in planning budget usage. In addition, it turns out that village governments sometimes have to change village-level regulations to ensure that the priorities set by district / municipal governments can be implemented. This means that village development planning in Ciburial conducted through musrenbang on its way must be changed because it is required to be adjusted with RKPD Kabupaten Bandung.

These conditions make Ciburial Village Government has no choice, but follow the will or direction given by the Government of Bandung Regency (in this case DPMD). The decision of the Ciburial Village Government is not without consideration, although the determination of development priorities in the village is inconsistent with the needs of the community and the village geographical condition. For example, when Ciburial Village Government is directed to work on concrete of village roads in Bandung Regency, whereas with the geographical condition of Ciburial Village, more precise penetration by paved concrete (hotmix). The decision is clearly not appropriate, let alone it is contrary to Regulation No. 2 of 2016 about KBU which gives the mandate to preserve the environment.

The Village Government's acceptance of the will of the local government to work on the concrete is due to not want to have a polemic with the Government of Bandung Regency. Another consideration is to minimize the risks that the village must bear. Therefore, following the direction and the will of the Government to be the best way so that the error that led to the existence of sanctions from the Government of Bandung Regency, can be minimized. The experience when managing village funds in 2015 is a mirror for Ciburial Village Government, while the establishment of a development plan still prioritizes the work plans set by the local government.

In further examination, the fact that the better the activity (concretization) is done for uniformity is a mistake. The geographical condition of the existing 270 villages in Bandung Regency is generally not the same, as is the case of Ciburial Village which is very different from the Soreang village located in the lowlands. Bandung regency is including the plateau region with a slope slope between the $0-8 \%, 8-15 \%$, and above $45 \%$. With a slope like that, then most of the Regency of Bandung is a hill and mountains. The reason for the uniformity of accountability report to be easily compiled or made is also clearly inappropriate because it has nothing to do with the type of activity. Bandung Regency Government itself has made the guidance through Regulation No. 21 of 2016 on Guidelines for Management of Village Funds in Bandung Regency. This should be enough for the village government to ensure that reports 
made on the use of village funds can be uniform with other villages. Therefore, the reason for the uniformity of activities to make accountability reports easily made is irrelevant.

In fact, as long as the village development does not conflict with the regent's regulation or higher level of regulation, it is the village's right to determine the direction of its development. The development of course also has been adapted to the needs and conditions of each village in Bandung Regency. However, the Bandung Regency Government seems to have its own views and interpretations of its policies, including a view that doubts the ability of all village governments in Bandung Regency to manage village funds to finance village development, so that intervention on the determination of village development direction becomes a necessity. This shows that the village has no power in determining the direction of village development policy based on the needs of the village and its people.

The problem that then arises is not in the easy or difficult to change the development plan and adjust it with the will of the government and the ease in preparing accountability report. This is due to changing the work plan is not a difficult thing because it can be done through changes in APBDes. So even with the preparation of accountability reports because the District Government has given guidelines. However, the main problem is that the involvement of the local government indicates that the village is perceived as unlikely to be able to manage large amounts of village funds.

Regardless of the demands of local governments to take responsibility for the management of the Village Funds, and making the Regional Government the fulcrum of establishing the rules of the village fund management, the involvement of the local government in the village development planning in Ciburial to the determination of village needs and its community shows that the village has no power over it. The village also seems to have no significant bargaining power to be able to sustain development planning based on community needs. The existence of a package of policies related to governance of village funds becomes meaningless because it does not become the reference of Bandung Regency Government (especially DPMD) when determining development priorities. Ciburial Village, which typically includes in developed villages, but in village funded development is directed to other village typologies and is required to carry out uniform development activities. This is of course contradictory to the mandate set forth in Permendes 22 of 2015 which provides the possibility of various forms of village development activities as priority setting should also be based on village typology.

In the context of autonomy and independence, the conditions experienced by Ciburial Village show that the autonomy of the village as a legal community can not be used as a basis in regulating and managing village development planning, especially in determining development priorities funded by village funds. The policy of Bandung Regency Government which is actualized by its regional apparatus is the Village Community Empowerment Office with its technical policy which stipulates the uniformity of activities for all village typologies to illustrate that the local government does not understand the context and content of the Government by issuing the village fund policy. The focus of the local government is only on the administration of village funds management, not on the intent and purpose of the policy of making the village prosperous and self-sustainable in a sustainable manner. This means that the local government only focus on itself is the reporting accountability of the use of village funds to the Central Government.

The explanation related to village-based development management in Ciburial Village is an unrealistic portrait of villages in planning their own village development. The autonomy of the 
village is only limited to the recognition of the state alone in legislation because in its empirical level, especially in development governance does not have the power to be implemented.

\section{CONCLUSIONS AND SUGGESTIONS}

Village-based development management in Ciburial as well as other villages starts with village meetings, village RKP drafting, Village RKP Design, Village APB Design, and APBDes review. This mechanism is in fact in accordance with the provisions set by the government. But in the empirical level, the determination of development priorities can not only be based on the needs of the community because the Regional Government of Bandung Regency instructed that the determination of development priorities funded by village funds should be based on the work plan of Bandung Regency.

The Ciburial Village Government has no choice but to follow the instructions. The choice of the Village Government is based on consideration for the smooth disbursement of village funds and the ease of reporting accountability for the use of village funds. In this case, the Village Government does not want to be polemic with the Regional Government especially with the Village Community Empowerment Office because they are the ones who are authorized by the Central Government related to the management of village funds. This condition provides an overview of the inconsistency of Ciburial Village in development planning in the village and the dominance of the Regional Government in relation to the Village. Thus it can be said that the condition becomes counter-productive because the country's hope that the future village will be self-sustained in a sustainable way is very difficult to be realized.

The root of the problem in this study lies in the understanding of the Regional Government, especially the Village Community Empowerment Office, which focuses too heavily on the administrative aspects of village financial governance, especially those sourced from village funds. As a result, not only the intent and purpose of the government to issue a village fund policy that is not reached, but also causes the hamper of village independence because the power to realize it is not given by the Regional Government. Therefore, it is necessary for the Local Government to emphasize its ranks (SKPD), especially those directly involved in the management of village funds to better understand the content and the context and purpose and objectives of the village's fund policy issued by the Government.

\section{Reference}

Arikunto, Suharsimi. 2005. Manajemen Penelitian. Jakarta: Rineka Cipta

Asy’ari, Sapari Imam. 1993. Sosiologi Kota dan Desa. Surabaya: Usaha Nasional

Beratha, I. Nyoman. 1982. Desa: Masyarakat Desa dan Pembangunan Desa. Jakarta: Ghalia Indonesia

Bungin, Burhan. 2007. Penelitian Kualitatif. Jakarta: Kencana Prenada Media Group

Cresswell. Jhon W. 20013. Research Design. Yogyakarta: Pustaka Pelajar

Devas, Nick, dkk. 1989. Keuangan Pemerintah Daerah di Indonesia. Jakarta: IU-PRESS

Eko, Sutoro. 2014. Desa Membangun Indonesia. Yogyakarta: Australian Community Development and Civil Society Huda, Ni'matul. 2015. Hukum Pemerintahan Desa. Malang: Setara Press

Jamaludin, Adon Nasrullah. 2015. Sosiologi Perdesaan. Bandung: Pustaka Setia

Kaho, Josep Riwu. 2012. Analisis Hubungan Pemerintah Pusat dan Daerah. Yogyakarta: PolGov

Kartohadikoesoemo, Sutardjo. 1984. Desa. Jakarta: Balai Pustaka

Leibo, Jefta. 1986. Sosiologi Pedesaan : Mencari suatu Strategi Pembangunan Msyarakat Desa Berparadima Ganda.

Yogyakarta : Andi Offset 
M Manulang. 2009. Dasar-Dasar Manajemen. Yogyakarta: Gadjah Mada University Perss

Mardiasmo, 2004. Otonomi \& Manajemen Keuangan Daerah. Yogyakarta: Andi Yogyakarta

Miles, Matthew. B dan A. 1992. Michael Huberman. Analisis Data Kualitatif. Jakarta: UI-PRESS

Moleong, Lexi. 2007. Metode Penelitian Kualitatif. Bandung: PT. Remaja Rosdakarya Offset.

Moleong, Lexy J. 1996. Metodologi Penelitian Kualitatif. Bandung : PT. Remaja Rosdakarya

Ndraha, Taliziduhu. 1990. Pembangunan Masyarakat-Mempersiap Masyarakat Tinggal Landas. Bandung: Rineka Cipta.

Ndraha, Taliziduhu. 2003. Kybernology (Ilmu Pemerintahan Baru) Jilid 1. Jakarta: Rineka Cipta.

Ndraha, Taliziduhu. 2003. Kybernology (Ilmu Pemerintahan Baru) Jilid 2. Jakarta: Rineka Cipta.

Nurcholis, Hanif. 2011. Pertumbuhan dan Penyelenggaraan Pemerintahan Desa. Jakarta: Erlangga

Rahardjo, Adisasmita, 2006. Pembangunan Pedesaan dan Perkotaan. Yogyakarta: Graha Ilmu

Rasyid, Muhammad Ryaas. 2007. Makna Pemerintahan. Jakarta: PT Mutiara Sumber Widya

Riawanti, Selly.2003. Metode Kualitatif dalam Ilmu-Ilmu Sosial. (modul) Kerjasama Inspektorat Jendral

Departemen Pendidikan Nasional dan Lembaga Penelitian Unpad

Soekanto, Soerjono. 2001. Sosiologi Suatu Pengantar. Jakarta: Rajawali Press

Sugiono. 2007. Metode Penelitian Kualitatif. Bandung : Alfabeta

Sukmadi, S.E., MM. 2012. Dasar-Dasar Manajemen. Bandung: Humaniora

Surianingrat, Bayu. 1981. Pemerintah dan Administrasi Desa. Bandung: Aksara Bandung . 1992. Mengenal Ilmu Pemerintahan. Jakarta: PT RINEKA CIPTA

Suyanto, Bagong. 2010. Metode Penelitian Sosial. Jakarta: Kencana Prenada Media Group

Peraturan Perundan-undangan

UU No 23 Tahun 2014 Tentang Pemerintahan Daerah

UU No 6 Tahun 2014 Tengtang Desa

Peraturan Pemerintah No 72 tahun 2005 tentang Desa

Peraturan Menteri Desa, Pembangunan Daerah Tertinggal, dan Transmigrasi Nomor 21 tahun 2015 tentang Penetapan Prioritas Penggunaan Dana Desa tahun 2016

Permendagri 84 tahun 2015 tentang SOTK Pemerintahan Desa

Peraturan Bupati Bandung No 21 Tahun 2016 Tentang Pedoman Pengelolaan Dana Desa di Kabupaten Bandung 